\title{
DISCOVERY OF AN HADAMARD MATRIX OF ORDER $92^{1}$
}

BY LEONARD BAUMERT, S. W. GOLOMB AND MARSHALL HALL, JR.

Communicated by F. Bohnenblust, December 29, 1961

An Hadamard matrix $H$ is an $n$ by $n$ matrix all of whose entries are +1 or -1 which satisfies $H H^{T}=n I, H^{T}$ being the transpose of $H$. The order $n$ is necessarily 1,2 or $4 t$, with $t$ a positive integer. R. E. A. C. Paley [3] gave construction methods for various infinite classes of Hadamard matrices, chiefly using properties of quadratic residues in finite fields. These constructions cover all values of $4 t \leqq 200$, except $4 t=92,116,156,172,184,188$. Further constructions have been given by J. Williamson $[5 ; 6]$, A. Brauer [1], M. Hall [2] and R. Stanton and D. Sprott [4]. Williamson's first paper gave an Hadamard matrix of order 172, incorporating a special automorphism of order 3 . The same method may be applied to $92,116,156$, and 188 , but Williamson did not do so, principally because of the amount of computation involved.

Williamson's method has been applied to $4 t=92$ using the IBM 7090 at the Jet Propulsion Laboratory. The matrix $H$ has the form

$$
H=\left|\begin{array}{rrrr}
A & B & C & D \\
-B & A & -D & C \\
-C & D & A & -B \\
-D & -C & B & A
\end{array}\right|
$$

where each of $A, B, C, D$ is a 23 by 23 symmetric circulant matrix. We give here the first row of each of $A, B, C, D$ writing + for +1 and - for -1 .

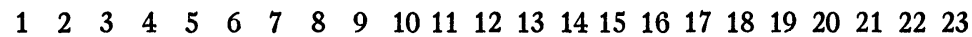

$$
\begin{aligned}
& \text { A }+ \text { + - - - + - - - + - + - + - - - + - - + } \\
& \text { B }+-++-++--++++++--++-++- \\
& \text { C }+++---++-+-++-+++--++ \\
& \text { D }+ \text { + }+-+++-+----+-+++-+
\end{aligned}
$$

\section{REFERENCES}

1. A. Brauer, On a new class of Hadamard determinants, Math. Z. 58 (1953), 219225.

1 The work reported in this paper was conducted at the Jet Propulsion Laboratory of the California Institute of Technology under a program sponsored by the National Aeronautics and Space Administration, Contract number NASw-6. 

986.

2. M. Hall, Jr., A survey of difference sets, Proc. Amer. Math. Soc. 7 (1956), 975-

3. R. E. A. C. Paley, On orthogonal matrices, J. Math. Phys. 12 (1933), 311-320.

4. R. G. Stanton and D. A. Sprott, A family of difference sets, Canad. J. Math. 10 (1958), 73-77.

5. J. Williamson, Hadamard's determinant theorem and the sum of four squares, Duke Math. J. 11 (1944), 65-81.

6. - Note on Hadamard's determinant theorem, Bull. Amer. Math. Soc. 53 (1947), 608-613.

California Institute of Technology

\title{
Neuerscheinung!
}

\section{Nichteuklidische Elementargeometrie der Ebene}

Von Professor Dr. Dr. h. c. O. PERRON, München

Mathematische Leitfäden. Herausgegeben von Prof. Dr. G. Köthe, Heidelberg

134 Seiten mit 70 Bildern. DIN C 5. 1962. In. DM 27,-

\begin{abstract}
Aus dem Inhalt: Grundbegriffe / Axiome / Begriff der Nichteuklidischen Geometrie / Parallelwinkel / Rechtwinkliges Dreieck und Spitzeck / Konstruktionsaufgaben / Hyperbolische und trigonometrische Funktionen / Berechnung des Parallelwinkels / Trigonometrie / Schniftpunktssäłze beim Dreieck / Flächeninhalt / Kreis: Grenzkreis / Abstandslinie / Widerspruchsfreiheit / Literatur / Namen- und Sachverzeichnis

In dem vorliegenden Werk wird die Nichteuklidische Geometrie aufgebaut, indem aus dem Euklidischen Axiomensystem das Parallelenaxiom ausgestrichen und durch seine Verneinung ersetzt wird. Der Aufbau erfolgt ohne zusätzliche Annahmen, wie sie Lobatschefskii, Bolyai und später Liebmann machen mussten, durch eine neuartige Berechnung des Parallelwinkels in aller Strenge, wobei auf Anschaulichkeit, leichte Fasslichkeit und engen Anschluss an die
\end{abstract} Schulgeometrie Bedacht genommen wird.

\section{B. G. TEUBNER VERLAGSGESELLSCHAFT • STUTTGART}

